\title{
Scanning Electron Microscopy of Plexus Choroideus in Adult Sheep
}

\author{
V. RAJTOVÁ \\ Department of Anatomy and Histology, University of Veterinary Medicine, Košice, Slovak Republic \\ Received January 25, 2001 \\ Accepted June 19, 2002

\section{Abstract} \\ Rajtová V .: Scanning Electron Microscopy of Plexus Choroideus in Adult Sheep. Acta Vet. Brno \\ 2002, 71: 279-282. \\ The outer morphology of the surface of the ependymal lining of the plexus choroideus was \\ studied within the whole ventricular system of the brain in adult sheep using a scanning electron \\ microscope. The more abundant occurrence of spherical secretory protrusions was found on the \\ plexus choroideus $(\mathrm{PCH})$ in the lateral cerebral ventricle. A frequent finding of the macrophage- \\ like epiplexal cells was recorded on the $\mathrm{PCH}$ in the region of the lateral as well as the fourth \\ ventricle. No differences were found in the structure of the PCH surface, which could be related to \\ the sexual differentiation of the sheep. Our results are compared, above all, with those found in the \\ adult goat and in the foetuses of both species of small ruminants. \\ Central nervous system, plexus choroideus, cerebral ventricles, adult sheep
}

Less attention has been paid to the study of the plexus choroideus as one of the structures of the ventricular system of the brain in different species of mammals using the scanning electron microscope than to the structure of the surface of the ependymal lining. In the prenatal but also in postnatal period, the surface of the $\mathrm{PCH}$ in laboratory rodents was observed by Yamadori (1972), Hosoya and Fujita (1973), Chamberlain (1974), Peters (1974), Mestres and Breipohl (1976), Peters and Swan (1979), in the dog (Allen 1975; Persky 1980), in the cat (Clementi and Marini 1972), in the rhesus macaque (Ling 1983), and in humans (Scott et al. 1972, 1974; Otani and Tanaka 1988, O'Rahilly and Müller 1990). In farm mammals the PCH was studied in the goat and sheep foetuses but also in the adult goat (Rajtova 1997, 2000). There is no record of the structure of the surface of epithelial cells that cover the PCH in adult sheep.

The aim of the work was to describe the epithelial surface of the $\mathrm{PCH}$ in the lateral, third and fourth cerebral ventricles in adult sheep with the aid of a scanning electron microscope.

\section{Materials and Methods}

Ten healthy adult sheep ( 5 ewes and 5 rams) were used. The animals were killed in March and October by exsanguination following thiopental anaesthesia. Immediately after exsanguination, the heads of the animals were perfused through the $a$. carotis communis with $0.2 \mathrm{~mol} / 1$ phosphate buffer solution and prefixed with Karnovsky solution. The specimens of the individual parts of the plexus choroideus were postfixed in $3 \%$ glutaraldehyde in $0.2 \mathrm{~mol} / \mathrm{l}$ cacodylate buffer. The temperature of the solutions was $4^{\circ} \mathrm{C}, \mathrm{pH} 7.4$. The specimens were processed by the method of Murakami et al. (1977), dehydrated, dried by the critical point method and coated with gold in vacuum. Then they were studied in the Tesla BS 340 scanning electron microscope with image analysis.

\section{Results}

The plexus choroideus ventriculi lateralis forms low folds. The periphery of the ependymal cells is irregularly round, almost elongated. The apical membranes of most lining ependymal cells are convex, covered with thick, short, densely arranged microvillus-like structures. Among them on numerous sites are abundant, predominantly small and spherical,

Address for correspondence:

Prof. MVDr. Viera Rajtová, DrSc.

Department of Anatomy and Histology

Komenského 73, 04181 Košice, Slovak Republic
Phone: +421556338192

Fax: + 421556323666

http://www.vfu.cz/acta-vet/actavet.htm 
but also some elongated protrusions (Plate I, Fig. 1). On the surface of the ependymal cells or between the PCH folds, epiplexal cells frequently occurred. The bodies of some of them are small, irregularly round with uneven surfaces. They have 2 or 3 short processes, which are almost all formed by "ruffled membranes" (Plate I, Figs 2, 4). The peripheral margins of these membranes could pass into the filiform elongations. Other epiplexal cells have their bodies oval with a smooth surface. These form 3-4 processes, which are changed to "ruffled processes" either totally or partly (Figs 1, 3).

The surface of the plexus choroideus ventriculi tertii is folded almost as much as in the lateral ventricle. The apical membranes of the lining ependymal cells are markedly convex (Plate II, Figs 5, 8). They are covered with dense fibrous microvilli that are not regular in height. The presence of small spherical protrusions as well as epiplexal cells is not frequent in this region; these structures occur, as a rule, in the deeper sites between folds (Plate xy, Fig. 6). The epiplexal cells have small, irregularly round, or elongated bodies from which more protrusions originate. These form "ruffled membranes" either on the periphery or all over (Fig. 5). Beside them, longer, thin, filiform processes can also originate from the body (Plate II, Fig. 7).

The surface of the plexus choroideus ventriculi quarti in adult sheep is especially folded, and forms numerous small glomoid structures (Plate III, Fig. 9). The apical membranes of the ependymal cells are convex, and covered with low, thin, densely arranged microvilli that are at some sites replaced with thick, dense, microvillus-like structures. Some small round almost elongated protrusions occur sporadically between microvilli (Plate III, Figs 9, 10, 12). The epiplexal cells are dispersed over many sites, above all, in the gaps between folds (Figs 9, 11, 12). Their bodies are predominantly oval almost tapering with 2-3 processes which either whole or partly form "ruffled membranes" on the periphery.

In all the sheep examined, no typical cilia were found on the surface of the entire $\mathrm{PCH}$; nor were differences between ewes and rams recorded.

\section{Discussion}

If the results in the adult sheep presently studied are compared with those in adult goats (Raj tová 2000) some common, but also different characteristics may be stated. The apical membranes of the ependymal cells of the $\mathrm{PCH}$ in both species of small ruminants are markedly convex and the PCH ventriculi quarti surface is the most folded, and therefore it is very fragile. In adult sheep, as in goats, almost the entire PCH surface is covered with thin microvilli or microvillus-like thicker structures. The typical cilia are absent. The small spherical or elongated protrusions of secretion in the adult sheep studied occurred abundantly on the $\mathrm{PCH}$ surface in the lateral and fourth cerebral ventricle, while in the region of the third ventricle their presence was rarer. Unlike in sheep, in adult goats the secretory protrusions were recorded only in the ventriculus lateralis (Raj tová 2000).

There was an abundant occurrence of epiplexal cells in goats in the third cerebral ventricle, above all, in the region of foramen interventriculare (Raj tová 2000); in adult sheep their presence was substantially lower. Their occurrence was recorded, especially in the fourth but also in the lateral cerebral ventricle.

Some authors, engaging in the description of supraependymal or epiplexal cells, have considered them as macrophages capable of movement and phagocytosis (Kit a mu ra 1973; Hosoya and Fujita 1973; Chamberlain 1974; Bleier et al. 1975; Sturrock,1983, 1988), or as the structures derived from the macrophages circulating in the blood (Carpenter etal. 1970; Ling 1983; B oya et al. 1986; Maxwell and McGadey 1988; Lu et al. 1993; Ling and Wong 1993; Ling et al. 1998).

The outer morphology of the PCH surface in adult sheep differs more substantially from that in the sheep foetuses (Raj tová 1997) than from that in the adult goat. In the sheep and 
goat foetuses, on the PCH besides microvilli, there are also typical cilia scattered or arranged in tufts. Unlike in the adult sheep (the same pertains to adult goats, Rajtova 2000) the occurrence of spherical secretory protrusions in the period of the prenatal life of sheep is very abundant, which would indicate a much more active prenatal than postnatal secretory activity of PCH. The presence of epiplexal cells on the foetal PCH of both species of small ruminants was limited only to the third and partially the lateral ventricle (Rajtová 1997), in adult sheep they were found in a greater number in the ventriculus quartus.

Even if we have recorded the presence of EPC on the PCH surface, and although their outer morphology is the same as that of some cells considered by other authors as macrophages on the PCH surface (Carpenter et al. 1970, Maxwell and McGadey 1988; Ling and Wong 1993; Ling et al. 1998) we have not made a statement about their origin, because our study in the scanning electron microscope was not supplemented by a confirmation in the transmission electron microscope or histochemically. The outer morphology of epiplexal cells in adult sheep and goats (Rajtová 2000), as well as in the foetal material from both species of small ruminants (Rajt ova 1997) is the same as their supraependymal cells under the physiological conditions (Rajtová 1988, 1990; Rajtová and Kačmarik 1998). Similarly according to Tseng et al. (1983) the epiplexal cells resemble the supraependymal and ameboid cells in the cavum septum pellucidum.

In adult sheep, as has been found in adult goats, it is also valid for their prenatal period (Rajtová 1997, 2000). No differences were recorded which would be connected with the sexual differentiation as was found in case of the ependymal lining of the cerebral ventricles of the brain.

\section{Plexus choroideus dospelej ovce: štúdium v riadkovacom elektrónovom mikroskope}

Práca sa zaoberá štúdiom povrchu epiteliálnej výstielky plexus choroideus $(\mathrm{PCH}) \mathrm{v}$ celom ventrikulárnom systéme mozgu u dospelej ovce pomocou riadkovacieho elektrónového mikroskopu. Na plexus choroideus (PCH) laterálnej komory boli nájdené hojné sférické protrúzie. Častý výskyt makrofágom podobných epiplexových buniek bol zaznamenaný na PCH v oblasti laterálnej, ale aj štvrtej komory. Neboli zistené rozdiely v stavbe povrchu $\mathrm{PCH}$, ktoré by súviseli so sexuálnou diferenciáciou oviec. V práci sa porovnávajú výsledky získané z dospelých oviec predovšetkým s údajmi u dospelých kôz ale aj plodov u obidvoch druhov malých prežúvavcov.

References

ALLEN, DJ 1975: Scanning electron microscopy of epiplexus macrophages (Kolmer cells) in the dog. J comp Neurol 161: 197-214

BLEIER, R, ALBRECHT, R, CRUCE, JA F 1975: Supraependymal cells of hypothalamic third ventricle: identification as resistant phgocytes of the brain. Science 139: 299-301

BOYA, J, CALVO, AL, GARCIA-MARINO, E 1986: Nature of macrophages in the rat brain. Acta Anat 127: 142145

CARPENTER, SJ, MCCARTHY, LE, BORDISON, HL 1970: Electron microscopic study of the epiplexus (Kolmer) cells of the cat choroid plexus. Z Zellforsch 110: 471-486

CLEMENTI, F, MARINI D 1972: The surface of the walls of cerebral ventricles and choroidal plexus in cat. Z Zellforsch 123: 82-95

HOSOYA, Y, FUJITA T, T 1973: Scanning electron microscope observation of intraventricular macrophages (Kolmer cells) in the rat brain. Arch Histol Jap 35: 133-140

CHAMBERLAIN, JG 1974: Scanning electron microscopy of epiplexus cells (macrophages) in the fetal rat brain. (1). Am J Anat 139: 443-446

KITAMURA, T 1973: The origin of brain macrophages, some considerations on the microglia theory of del Hortega. Acta Path Jap 23: 11-26

LING, EA, KAUR, CH, LU, J 1998: Origin, nature and some functional considerations of intraventricular macrophages, with special reference to the epiplexus cells. Microscop Res Techn 41: 43-56 
LING, EA 1983: Scanning electron microscopic study of epiplexus cells in the lateral ventricles of the monkey (Macaca fascicularis). J Anat 137: 645-652

LING, EA, WONG, WCH 1993: The origin and nature of ramified and amoeboid microglia: A historical review and current concepts. Glia 7: 9-18

LU, J, KAUR, CH, LING, EA 1993: Intraventricular macrophages in the lateral ventricles with special reference to epiplexus cells: a quantitative analysis and their uptake of fluorescent tracer injected intraperitoneally in rats of different ages. J Anat 183: 405-414

MAXWELL, WL, MC GADEY, J 1988: Response of intraventricular macrophages after a penetrant cerebral lesion. J Anat 160: 145-155

MESTRES, P, BREIPOHL, W 1976: Morphology and distribution of supraependymal cells in the third ventricle of the albino rat. Cell Tissue Res 168: 303-314

MURAKAMI, T, YAMAMOTO, K, ITOSHIMA, T 1977: Modified tannin-osmium conductive method for noncoated SEM specimens and application to microsection SEM of spleen. Arch histol Jap 40: 35-40

O-RAHILLY, R, MÜLLER, O 1990: Ventricular system and choroid plexus of the human brain during the embryonic period proper. Am J Anat 189: 281-302

OTANI, H. TANAKA, O 1988: Development of the chorioid plexus anlage and supraependymal structures in the fourth ventricular roof plate of human embryos: scanning electron microscopic observations. Am J Anat 181: 53-66

PERSKY, B 1980: Scanning electron microscopy of the epiplexus cells of the dog, gerbil and guinea-pig. Anat Rec 190: 508 (Abstract)

PETERS, A 1974: The structure of the choroid plexus and ependymal lining of the rat lateral ventricle. J Neurocytol 3: $99-108$

PETERS, A, SWAN, RC 1979: The choroid plexus and the mature and aging rat: The choroidal epithelium. Anat Rec 194: 325-354

RAJTOVÁ, V 1988: Ependym beim Schaf. 5. Teil: Ependymauskleidung der Gehirnkammern in Rasterelektronenmikroskop. J Hirnforsch 29: 231-235

RAJTOVÁ, V 1990: Ependyma of the goat. I. The third cerebral ventricle: Scanning electron microscopy study. J Hirnforsch 31: 415-421

RAJTOVÁ, V 1997: Chorioid plexus in sheep and goat: A scanning electron microscopy study of the foetuses. Acta Vet Brno 66: 199-202

RAJTOVÁ, V 2000: The plexus chorioideus in the adult goat: A scanning electron microscope study. Acta Vet Brno 69: 167-171

RAJTOVÁ, V, KAČMARIK, J 1998: Fetal ependyma in sheep and goat: A scanning electron microscopy study. Anat Histol Embryol 27: 131-134

SCOTT, DE, KOZLOWSKI, GP, SHERIDAN, MN 1974: Scanning electron microscopy in the ultrastructural analysis of the mammaliza cerebral ventricular system. Int res Cytol 87: 349-388

SCOTT, DE, PAULL, WK, KROBISCH-DUDLEY, G 1972: A comparative scanning electron microscopic analysis of the human cerebral ventricular system. Z Zellforsch 132: 203-215

STURROCK, RR 1983: A light and scanning electron microscope study of intraventricular macrophages in the brains of aged mice. J Anat 136: 761-771

STURROCK, RR 1988: The beta astrocyte: Its possible role as a central nervous system phagocyte. Anat Anz 166: 331-340

TSENG, CY, LING, EA, WONG, WC 1983: Scanning electron microscopy of amoeboid microglial cells in the transient cavum septum pellucidum in pre- and postnatal rats. J Anat 136: 251-263

YAMADORI, T 1972: A scanning electron microscopic observation of the choroid plexus in rats. Arch Histol Jap 35: $89-97$ 
Plate I

Rajtová V.: Scanning ... pp. 279-282

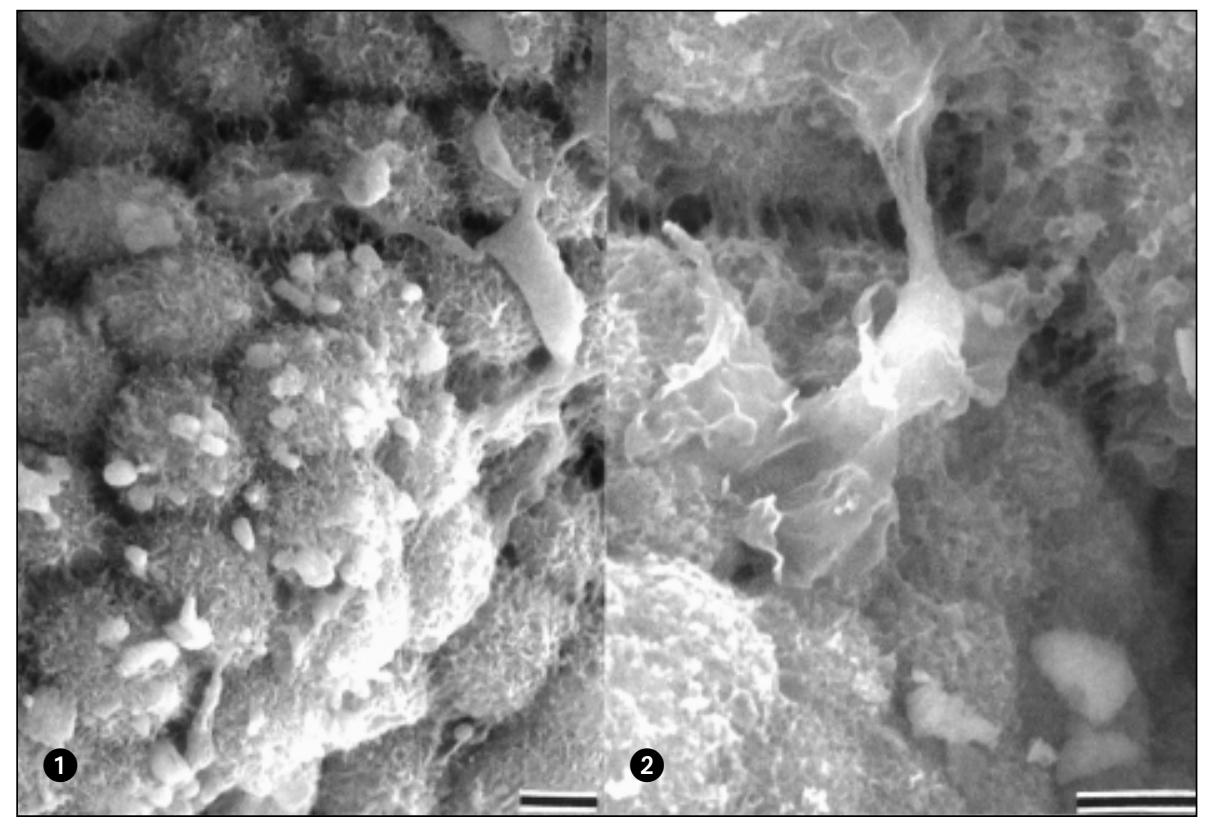

Figs 1-4. Details of the plexus choroideus ventriculi lateralis. The surface of apical membranes is more or less covered by thicker microvillus-like structures. Small spherical to prolongated protrusions are abundant. The occurrence of the epiplexal cells is frequent. Bars: Fig. $1=5 \mu \mathrm{m}$, Figs 2 - $4=5 \mu \mathrm{m}$.

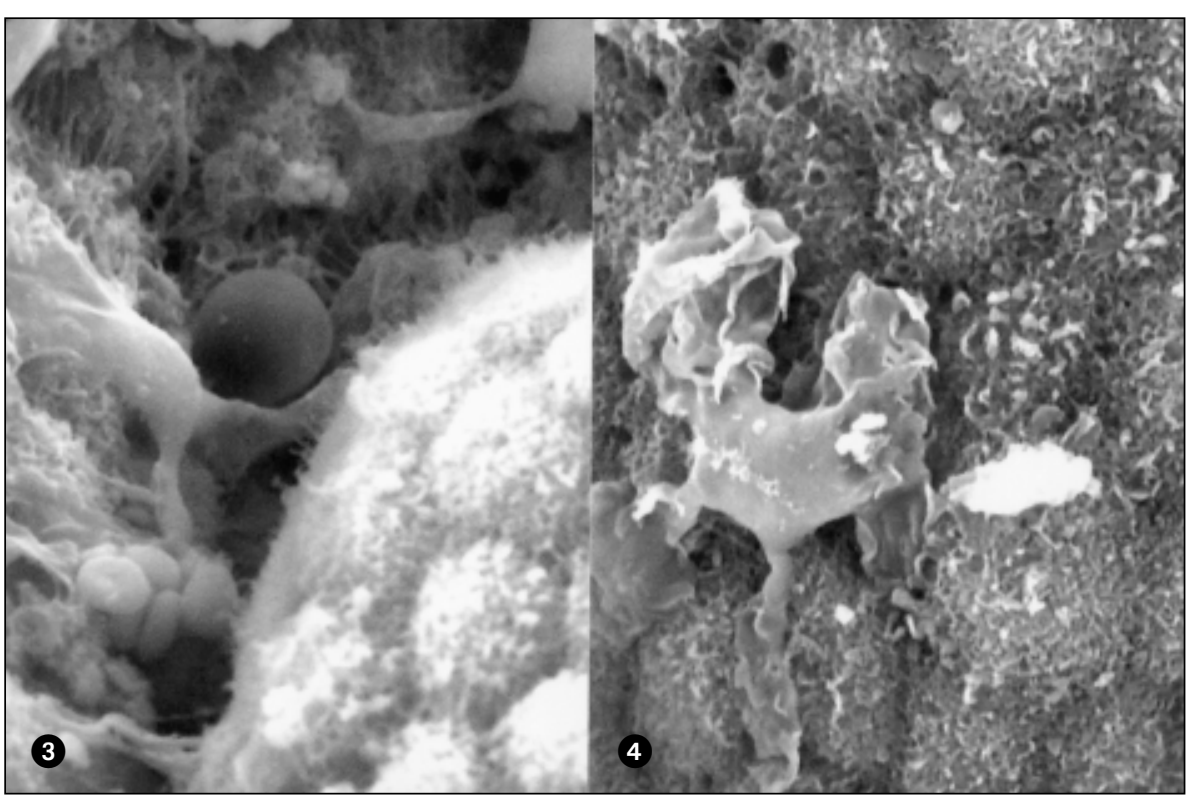


Plate II

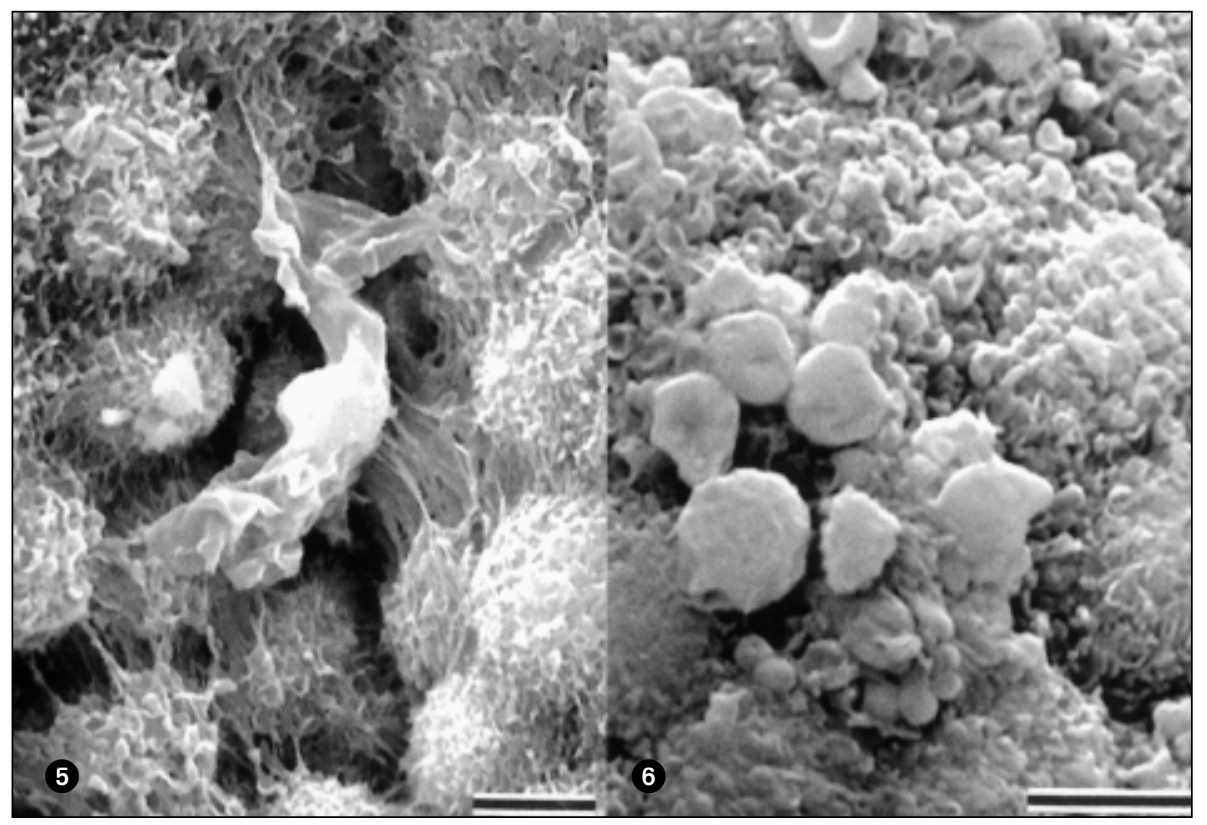

Figs $5-8$. The surface of the convex apical membranes of the plexus choroideus ventriculi tertii cover filiform and thick, microvillus-like structures. The occurrence of small spherical protrusions is rare. Isolated epiplexal cells have rounded or elongated bodies with filiform processes (arrows), and the processes which form "ruffled membranes". Bars: Figs 5, $8=5 \mu \mathrm{m}$, Figs 6, $7=5 \mu \mathrm{m}$.

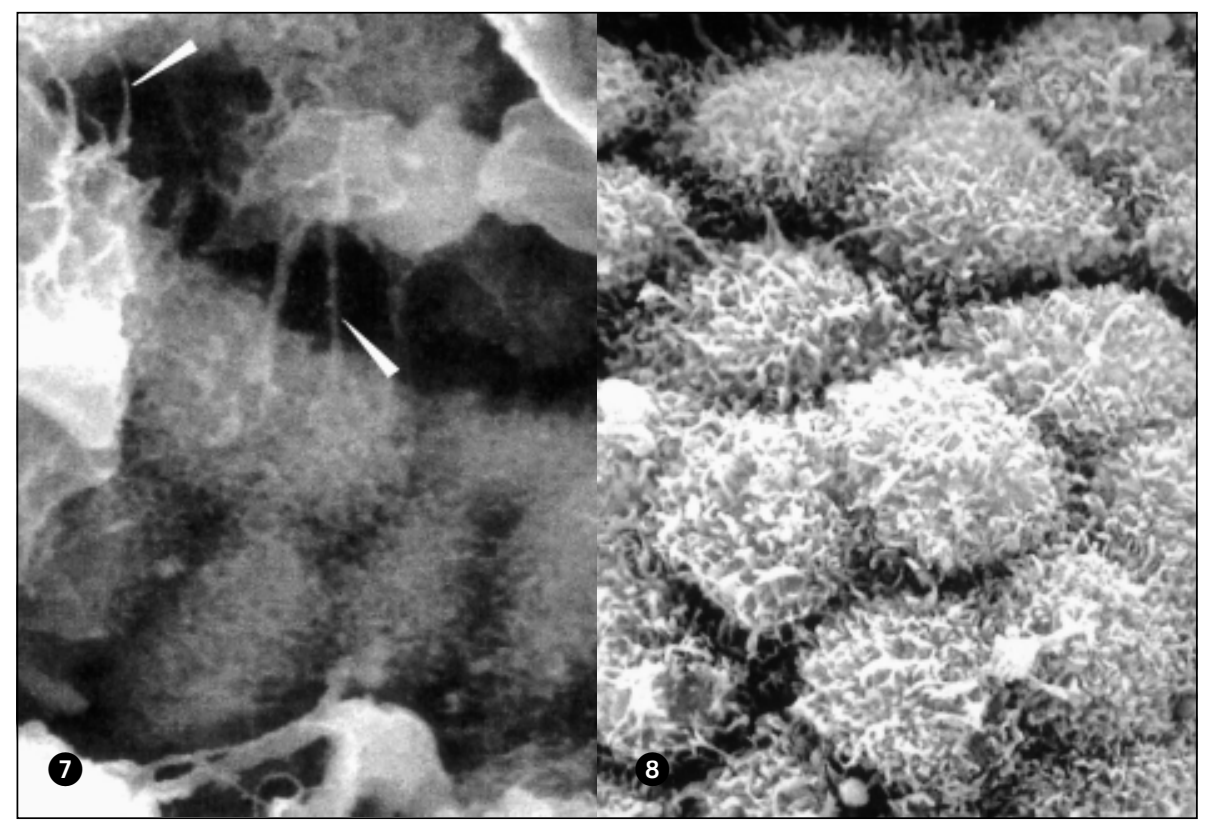


Plate III

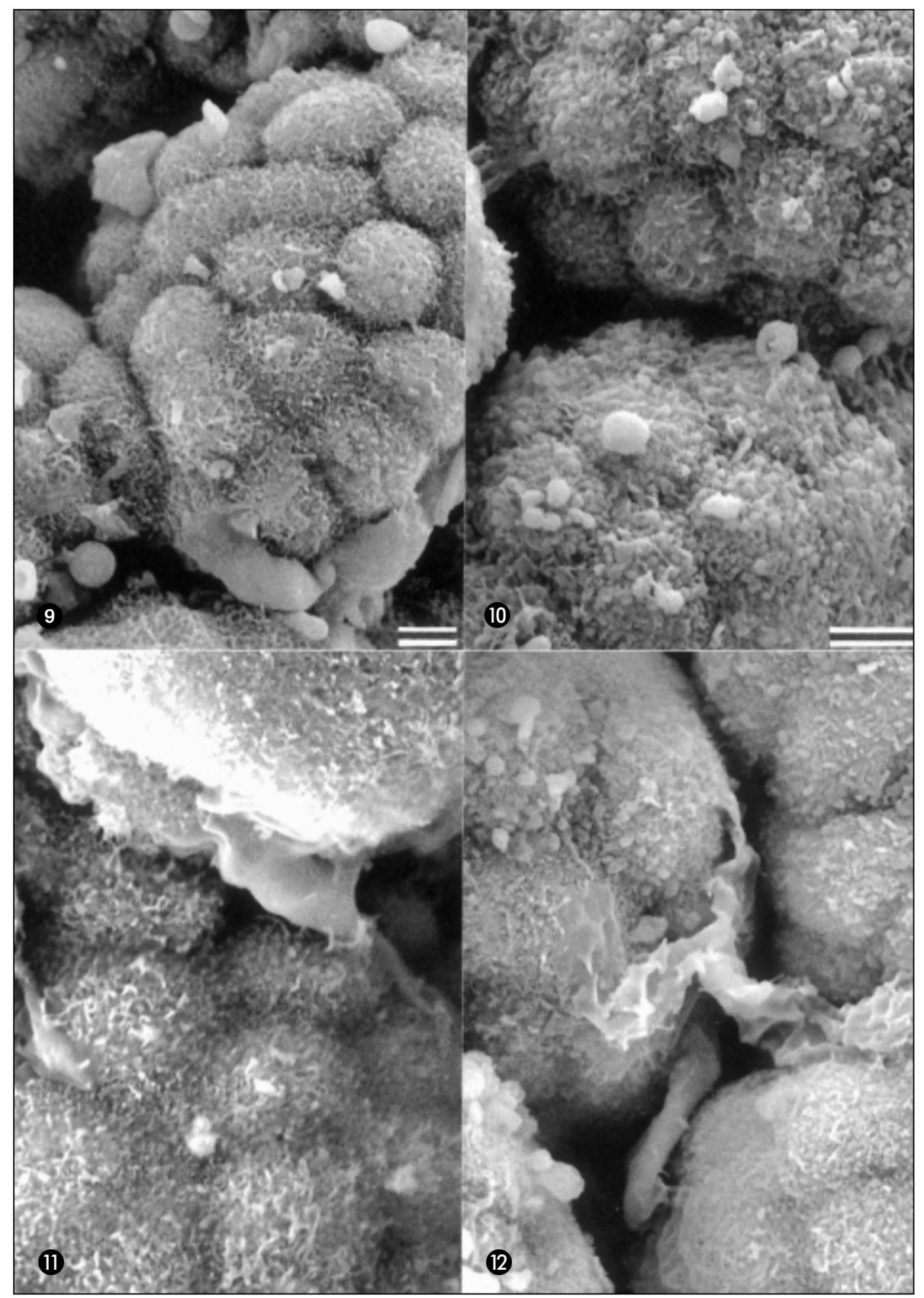

Figs 9 - 12. The surface of the plexus choroideus ventriculi quarti consists of the glomoid formations. The convex apical membranes, apart from except the microvilli and microvillus-like structures, cover small abundant spherical protrusions. The epiplexal cells have two or more processes forming the "ruffled membranes". Bars: Fig. $9=5 \mu \mathrm{m}$, Figs $10-12=5 \mu \mathrm{m}$ 